\title{
Representations of the Irish in American Vaudeville and Early Film
}

JENNIFER MOONEY, University of Ulster

\section{ABSTRACT}

The emergence of vaudeville and, later, moving pictures coincided with a period of increased immigration to the United States and both relied heavily on ethnic stereotypes for material. This paper will examine some of the ways in which one particular ethnic group, the Irish, were represented on stage and screen in late nineteenth and early twentieth century America. It will attempt to tie the portrayal of Irish ethnicity into wider debates around the nature of audiences for vaudeville and early cinema, and the impact which these mass media may or may not have had on urban, working class, immigrant audiences. I will consider the extent to which vaudeville and early cinema might have functioned as assimilationist tools, not only in relation to newly-arrived Irish immigrants but also those joining the steadily increasing numbers of middle class Irish Americans.

\section{KEYWORDS}

Irish, Irish America, vaudeville, early film, ethnic stereotypes 


\section{Introduction}

Earlier this year the release of the videogame Red Dead Redemption, which is set in the American Wild West and features a town drunk named 'Irish', prompted much discussion in the media, with The Irish Times questioning whether the Irish will forever be portrayed as 'Drunken Paddies' on screen (O'Connell, 2010). Stereotypical portrayals of the Irish are nothing new. The Norman chronicler Gerald of Wales wrote in the twelfth century that, while they were incredibly skilled at music the savage Irish were 'a fierce and barbarous' people (cited by Martin, 1969: 288-89). A wide range of stereotypes have been associated with the Irish over the years, some of which have endured to the present day - the simian-featured Irish Americans drawn by American comic artists such as Thomas Nast and Frederick B Opper for magazines like Puck and Harper's Weekly (Curtis, 1997: 58-67), the romantic and often sentimental portrayal of Ireland and the Irish in films like The Quiet Man (John Ford, 1952), and the corrupt and/or renegade Irish cop like Captain McCluskey in The Godfather (Francis Ford Coppola: 1972) or The Wire's Jameson's-swigging McNulty.

In this paper I will consider some of the stereotypes associated with the Irish in two emergent mass media of the late nineteenth and early twentieth centuries, vaudeville and early cinema. This paper is not intended to be a comprehensive survey of the varied and complex ways in which American popular culture represented the Irish around the turn of the century. Rather, I have tried to consider a small selection of Irish-themed vaudeville acts and early films in light of the historical context and socio-economic status of the Irish in America around the turn of the twentieth century. The vaudeville sketches and films cited throughout are drawn from a range of primary and secondary sources. For some of the films referred to I have relied on the synopses provided in Kevin Rockett's Irish Filmography and Kemp R Niver's catalogue of early motion pictures held in the paper print collection of the Library of Congress (Rockett, 1996; Niver, 1985). In addition, my own research in a sample of early US trade periodicals, specifically Variety, Nickelodeon and Moving Picture World, has identified some further acts and films with Irish characters or themes. I have indicated in my filmography where a film, to my knowledge, is extant and provided relevant details as to how it might be viewed.

\section{Audiences for vaudeville and early film}


The emergence of first vaudeville and then moving pictures as forms of mass entertainment coincided with a period of rapid social change in the United States. Between 1870 and 1890, industrial output increased by 500 per cent. Whereas in 1830 one in every fifteen Americans lived in cities with a population of more than 8,000 , by 1900 that proportion had increased to one third (Kimmel, 2006: 57-8). Immigration too increased - in the four decades from 1871 until 1910 there were more than 20 million immigrants to America (Dinnerstein and Reimers, 1977: 11). The number of Irish-born immigrants in the United States peaked in 1890 at 1.87 million. The number of second generation Irish-Americans peaked in 1900 at 3.37 million (Blessing, 1980: 528). Like many migrant groups, the Irish experience in America was a largely urban one. By 1920, 90 per cent of all Irish Americans lived in urban areas and Irish immigrants were almost twice as likely to settle in cities as the population of the United States as a whole (Blessing, 1980: 530). However, whereas in the mid-nineteenth century the Irish made up almost half of total immigrants to the United States (Blessing, 1980: 528), by the turn of the century they had been replaced as one of the dominant immigrant groups in America by new arrivals from Southern and Eastern Europe. In the first decade of the twentieth century, for example, there were almost 8.8 million immigrants to the United States, of which the Irish made up less than four per cent (Dinnerstein and Reimers, 1977: 11, 164). So while the Irish American population at the turn of the twentieth century was certainly numerous, they were only one of many ethnic groups living and working in American cities.

Vaudeville was a distinctly American entertainment centred largely in these increasingly populous and ethnically diverse cities, and has been described as the most popular form of theatre in turn of the century America (Lewis, 2003: 315; Snyder, 2006: 406). It had its roots in the boisterous, lower-class surroundings of the concert saloon and variety theatre and, as that name suggests, a show would typically consist of a wide range of acts, from dramatic plays and comic sketches through to troupes of acrobats and performing animals. Robert Snyder suggests that vaudeville attracted what was the first mass audience - men and women, families, working class and middle class, and native-born Americans and immigrants - and that it 'taught white Americans of vastly different origins how to get along together in public' (Snyder, 2000: xxv). A contemporary survey of the vaudeville audience suggested that on average it was 60 per cent working class, as opposed to two per cent for the more highbrow, 'legitimate' theatre (Davis, 1911 cited Snyder, 2000: 105). So, as Snyder (2000: 161) has argued, while vaudeville was not a uniformly open and egalitarian form of entertainment, it was more open and egalitarian than most other cultural institutions of the time.

From the late nineteenth century moving pictures began to take their place on vaudeville programmes and eventually went on to eclipse vaudeville as the mass medium. In 1912 one theatre 
manager noted that many vaudeville theatres depended on films for their profits and by 1928 only four theatres remained in the United States which offered vaudeville without films (Snyder, 2000: 157). As Robert Allen (1977: 5) points out, vaudeville provided not just the venues for film exhibition but also 'an almost instant national audience' for the nascent film industry. At least from the beginning of the nickelodeon period (approximately 1906 to 1914) moving pictures were an extremely popular form of entertainment. An article in Variety in 1907 suggested that more than two million people attended nickelodeons every day of the year (1907: 33). There has been some debate about the composition of the early cinema audience and the impact of films on that audience. The traditional view was that from the outset American film was a truly popular and populist form of mass entertainment, appealing to working class and immigrant audiences, and that it played an important role in assimilating these new arrivals into a modern American society. These grand claims for the power of the film are epitomized in Jacobs' The Rise of the American Film. According to Jacobs,

The movies gave the newcomers [...] a respect for American law and order, an understanding of civic organization, pride in citizenship and in the American commonwealth [...] More vividly than any other single agency they revealed the social topography of America to the immigrant, to the poor, to the country folk. (1968: 12)

However, recent studies of Jewish and Italian filmgoers in early 1900s New York suggest that rather than shaping these immigrants into American citizens early cinema, through the exhibition of European-produced films and integration of foreign language vaudeville acts, could actually serve to reinforce or in some case even create ethnic identities (Thissen, 1999; Bertellini, 1999). These examples raise questions over the extent to which cinema played an assimilationist role and question the relationship between mass entertainment and the construction of an 'American' identity among ethnic groups in the United States.

As Michael Pickering (2001) suggests, stereotypes tend to proliferate at times of rapid change and are often employed to maintain and underline normal behaviour patterns and strengthen identity in response to a perceived threat from that which is 'other'. It is unsurprising then, given the increasing industrialisation, urbanisation and immigration referred to above, that both American vaudeville acts and films relied heavily on ethnic stereotypes for their material. The ethnic nature of vaudeville programmes can be seen from contemporary reviews and advertisements. For example, for the week of 3 March 1906 the Family Theatre on East $125^{\text {th }}$ Street, New York, featured the following acts - Rhoda Bernard, described as 'a female Hebrew impersonator'; 'the Matzumota troupe of Japanese acrobats'; Harry and Mae Howard, a pair of German singers and 
clog dancers; and Louise Arnott and Thomas Gunn in Regan's Luck, in which Miss Arnot was described as playing 'a very good Irishwoman with a deep voice' (Variety, 1906: 8). Early films too drew on the ethnic diversity of the United States for material. Kevin Rockett (2009: 18) suggests that during the silent film era, as many as 500 American films were made with identifiable Irish themes or characters. Similarly, Lester Friedman (1987: 130) has identified over 230 films made between 1900 and 1929 which featured Jewish characters. A catalogue of the early motion picture holdings in the Library of Congress also illustrates the ethnic flavour of some early films. A film entitled Chinese Rubbernecks (AM\&B: 1903) featured, according to the catalogue's synopsis, two characters dressed as 'Chinese laundrymen' with pigtails having a fight. Cohen's Advertising Scheme (Edison: 1904) depicts the Jewish character Cohen as a miser who, ostensibly through an act of charity, actually advertises his store by giving a passing tramp a coat with his business name on the back (Niver, 1985: 55, 61). Below I consider some specific examples of the various Irish stereotypes found in vaudeville and moving pictures in the late nineteenth and early twentieth centuries and consider why these stereotypes may have originated and how they might have functioned in terms of defining normal behaviour.

\section{The Irish at work}

Kerby Miller (1985: 315) suggests that the Irish in the United States had traditionally been disproportionately represented in the lowest paid, least skilled and most dangerous jobs. In New York in 1880 the two largest categories of occupation for the Irish were domestic service and unskilled labour (Wittke, 1970: 25). However, by the turn of the century the situation had begun to improve, particularly for the American-born children of Irish immigrants. Of the 15 per cent of Irish men working as unskilled manual labourers in 1900 the majority were recent arrivals from Ireland. For women too the difference between first and second generation Irish Americans was marked. In 1900 almost two thirds of Irish-born women working in the United States were employed as domestic servants, compared to only 19 per cent of their American-born counterparts (Kenny, 2000: 185-86).

Despite some improvements in the working conditions of the Irish in America, vaudeville sketches and early films from the turn of the century often drew on the experiences of the Irish working classes for material, portraying them as accident-prone and ignorant of the ways of modern, urban America. According to Robert Snyder, the typical Irish character in vaudeville appeared dressed in 'a take off on an immigrant workingman's garb: a plaid suit, green stockings, corduroy breeches, a 
square tailed-coat, a battered stovepipe hat with a pipe stuck in the band, a hod-carriers rig, and chin whiskers'(2000: 113). In films such as Drill Ye Tarriers Drill (AM\&B, 1900) and Brannigan Sets Off the Blast (AM\&B, 1906:) the Irish working man in America is shown unshaven, in work clothes, smoking a pipe and behaving as if drunk. In both films he is accidentally blown up by explosive charges largely as a result of his own carelessness. Working-class Irish women also provided comedy material, with the character of the Irish servant or cook making frequent appearances on the vaudeville stage and in early films. In a letter to the Metropolitan Record in 1860 a Dr Cahill complained of Irish servants that they were 'ignorant of the common duties of servants in respectable positions. They can neither wash nor iron clothes. They don't understand the cleaning of glass or silver plate. They cannot make fires expeditiously, or dust carpets, or polish the furniture' (cited by Wittke, 1970: 44). This perceived incompetence of Irish domestic workers was lampooned in the Russell Brothers' vaudeville act The Irish Servant Girls, a knockabout comedy in which the two brothers came on stage in dresses and aprons, wearing red wigs and green ribbons, winking at men in the audience and exposing their underwear (Kibler, 2005: 5). The figure of Bridget the Irish maid became something of a stock character in early films. In How Bridget Served the Salad Undressed (American Mutoscope Co, 1898) the maid misinterprets her employer's request to serve the salad without dressing with predictable consequences (Rockett, 1996: 230). In How Bridget Made the Fire (AM\&B, 1900) the maid is played by a man, perhaps mocking the perceived lack of femininity among these Irish workers. In frustration at her inability to light the stove, she pours kerosene on it and is duly blown out of the window. In Why Bridget Stopped Drinking (Edison, 1901) a chemistry professor rigs up a skeleton and bucket of water in an attempt to stop his cleaner drinking his alcohol (Rockett, 1996: 234).

As I mentioned above, by the turn of the twentieth century the Irish in America had begun to move up the occupational ladder. These middle-class, 'lace curtain' Irish, as they were known, were often mocked for their attempts at respectability. Snyder, for example, points to the vaudeville character of Mike Haggerty who appeared on stage dressed in a formal frock coat set off by hobnail boots (2000: 113-4). The disastrous consequences that resulted from Irish attempts to behave like their native-born American counterparts are also evidenced in a range of comic songs written for the vaudeville stage such as 'Miss Mulligan's Home Made Pie' (1885), 'McFadden's Uptown Flat' (1890) and 'Mrs McCarthy's Party' (1888) (Williams, 2002: 10-11). These newly affluent Irish types are perhaps best represented by such stereotypical characters as the Irish cop or politician. By 1890 the Irish dominated urban American politics, particularly the machines of the Democratic Party. The 'bosses' were Irish, as were those working for the machines on the ground as 'ward fixers'. This domination came about largely because mid-nineteenth century politicians saw in the 
vast swathes of Irish immigrants arriving in their cities potential voters and offered favours in return, often in the form of government jobs in the police force or fire service (Kenny, 2000: 21012). By the turn of the twentieth century the Irish made up 11 per cent of the United States police force but in some cities were over-represented in this occupation (Blessing, 1980: 531). In 1888 for example 16 per cent of the population of New York was Irish, yet they made up 28 per cent of the city's police force (Wittke, 1970: 60).

Irish ties with the Democratic Party, and in particular the perceived corruption of the party political machine, are addressed in a number of vaudeville acts. In a vaudeville song entitled 'The Sound Democrat', the character Mike McNally boasts that he owns 'the eighth ward and population' and that he is therefore guaranteed a nomination at the next election. In Edward Harrigan's vaudeville play The Mulligan Nominee, Dan Mulligan gets the New York City aldermen drunk on whiskey. When his wife Cordelia sees that they have all fallen asleep and panics, Dan retorts 'lave them be. While they sleep, the city's safe' (Williams, 1996: 140-1). A 1911 vaudeville sketch entitled The Irish American Ex-Congressman features a character called $\mathrm{Mr}$ Dunderhead McNally and is peppered with 'begorreys' and 'bejabors' (Gaskell \& Landrum, 1911). The character of the Irish cop in American popular culture during this period tended to be presented as an ineffective, womanising, but essentially good-natured joker. The vaudeville song by Edward Harrigan and David Braham ‘Are You There Moriarty’ features a laid-back, good-humoured Irish policeman who is something of a hit with the ladies on his beat (Moloney, 2006). Referencing the links between the Irish, the Democratic Party and the police force, a 1907 vaudeville song entitled 'Tammany' (after the headquarters of the Democratic Party in New York) claimed that 'fifteen thousand Irishmen from Erin came across,/ Tammany put these Irish Indians on the police force' (Williams, 1996: 139). A 1909 vaudeville sketch entitled Policeman O'Reilly on Duty features a policeman with a strong Irish brogue willfully misunderstanding requests for information, passing comic asides on an overweight woman, and relieved to have been found on his post by his superior given that a few minutes earlier he would have been 'conspicuous by [his] absence'.

In the film Congress of Nations (Edison, 1900) a magician produces a range of characters with certain national traits on stage. According to the Edison catalogue, 'the magician adds a bit of comedy to the scene by producing a decidedly Hibernian policeman from the flag of Erin's isle' (Rockett, 1996: 231). The Policeman's Revolver (Essanay, 1909) features an Officer O'Toole and his sweetheart Kathleen, who causes panic when she runs after him waving the gun that he has forgotten (Moving Picture World, 1909: 969). In Mulcahy's Raid (Essanay, 1910), Officer Mulcahy encounters a group of moving picture actors dressed as policemen and, mistaking them for 
his colleagues, enlists their help to break up an illegal gambling ring. When the arrests have been made the actors return to their shoot, leaving Mulcahy to take the credit for the raid and he is awarded with a medal of 'the League of the Brave and Fearless' (The Nickelodeon, 1910a: 79). Similarly inept Irish cops are also mentioned in reviews of films such as Where is Mulcahy (Essanay, 1910), described in Moving Picture World as 'a very humourous story of a policeman stuck in a fence, tormented by boys' (1910a: 942); Officer Muldoon's Double (Lubin: 1910), in which the cop falls asleep on his post and a passing actor impersonates him (Moving Picture World, 1910a: 965); and The Troubles of a Policeman (Pathé, 1910), in which Officer Clancy dives into the Hudson river to rescue a boy who, it transpires, can swim better than him (Moving Picture World, 1910b: 520).

In some early films the Irish cop and Irish housekeeper appear to have a very close relationship. A review of Maggie Hoolihan Gets a Job (Pathé, 1910) reports that the film concerns a woman 'just come over from one of the little villages in the remote west of Ireland' and eager to make her fortune in the United States. She gets a job as a maid but inadvertently brushes her employer's coat with the carpet sweeper and then drops it in the street. Her 'fresh rosy cheeks' soon attract the attention of an Officer Clancy and the two become 'fast friends'. Officer Clancy uses his influence to get her other jobs, first in a laundry and then in the station house, but neither ends well - she destroys expensive lingerie and allows the prisoners to escape. At the end of the film, according to this review, the natural order of things is restored. Clancy decides to marry Maggie and 'give her a permanent job for life' looking after his ten children. Here she settles down and 'leaves it to Clancy to get together the fortune she hoped to make' (Moving Picture World, 1910b: 537). So as well as presenting a stereotypical image of an Irish cop, this film (or at least its synopsis) might be seen as reflecting an uneasiness at Irish women seeking independence in America and celebrating the maintenance of traditional gender roles. A similar viewpoint is echoed in When Women Vote (Lubin,1907), an anti-suffrage film featuring the character of Mrs O'Brien whose 'henpecked husband' is left to look after the baby and do the chores while she takes up a political career. In this nightmare vision where women vote, female police officers also 'control the beat'. Mrs O'Brien is elected judge and sentences a man to twenty years hard labour for kissing his wife. According to the production company's synopsis, 'Mr O'Brien would like to get a divorce, but such cannot be obtained when women vote' (Moving Picture World, 1907a: 252).

While it seems it was desirable for Irish women to stay in their place, for Irish men the desire to 'get ahead' in America was on occasion celebrated by early producers. Although the films referred to above would seem to portray the Irish cop as an inept character and one willing to make the most of 
his position for personal gain, some films provide a more positive portrayal of the Irish presence in the police force. Caught by Wireless (Biograph, 1908) features, according to Moving Picture World, a young man forced to leave Ireland for America who joins the police and earns enough money to send for his family (Moving Picture World, 1908a: 241). This epitome of the American Dream, in which America acts as a civilizing influence and a safe refuge for the Irish away from the political difficulties at home, can also be seen in A Son of Erin (Pallas Pictures, 1916). In this film a young Irish man travels to America, hailed in an intertitle as 'the land of promise', gets involved in politics in support of an anti-corruption candidate, convinces his fellow immigrants to vote for reform, and becomes a police captain (Rockett, 1996: 291). In a review of Clancy (Vitagraph, 1910), this particular Irish cop is described as 'a hero, a conscientious, fearless custodian of the public peace and property' who, having worked his way up to sergeant, is killed on duty. An advertisement for the film on the front cover of the same trade paper refers to the police as 'martyrs to duty and service' (The Nickelodeon, 1910b: 344).

\section{'Drunken Paddies'?}

Despite their apparent progress by the turn of the century, the Irish in America still faced certain hardships. A 1910 study found that the Irish accounted for the largest number of paupers in the United States, more than twice the rate for the next immigrant group (Kenny, 2000: 200). A 1918 statistical review presents some alarming data regarding overall health and mortality rates among Irish Americans, including levels of alcoholism. According to this study, the death rate from alcoholism among Irish males stood at 2.90 per 1,000 of the population. This rate was three times that of the German population, five and a half that of the English population, and over twenty-five times more than the Italian population. Alcohol too resulted in a high proportion of Irish among patients with mental illnesses, with 'Irish alcoholic insanities [being] from two to three times more frequent than those of any other people that come to the United States' (O'Malley, 1918: 630-1).

The Irish drunk is a common character in plays and films of this period. In Casey's Frightful Dream (Edison, 1904), for example, Casey falls out of bed during a dream that he is walking on the roof. He offers a prayer of thanks that he has not fallen off the roof and then hits the bottle for comfort. The 1907 film Fights of Nations (AM\&B, 1907) highlights the reliance of early film on recognisable ethnic stereotypes, with different sections including 'Hoot Mon, A Scottish Combat', 'Sunny Africa, $8^{\text {th }}$ Avenue, New York' and 'Sons of the Ould Sod'. According to the production company's publicity material this last section is 'a laughable scrap between Haggerty and Fogarty 
... the men battle furiously until that soothing balm to hurt feelings, beer, is proffered by the ever thoughtful Mrs Haggerty' (cited Library of Congress American Memory Collection: online reference). The section shows a woman hanging out washing from a tenement house and dropping a wet sheet on top of her neighbour. Her husband and the neighbour, both dressed in working man's clothes and bearing the trademark Irish whiskers, begin to fight, with the woman also joining in the fray. Eventually the woman leaves the stage, returns with a pale of beer, and the men drink and make up. This short section epitomises one of the most enduring Irish stereotypes, that of the belligerent, but ultimately harmless and good-natured, Irish drunk. Although the Irish propensity for alcohol addiction is well documented, the reasons for this are unclear. However, one historian has suggested that the stereotype of the fun-loving Irish drunk acted almost as a self-fulfilling prophecy. According to Richard Stivers (1976 cited Kenny, 2000: 201) alcohol became so linked to Irishness that conforming to the stereotype of the drunken Paddy became in itself a way to reaffirm an Irish-American ethnic identity.

\section{Why Irish?}

In the sketches and films referred to above the titles quite often identify the Irishness of the characters. What is particularly interesting though is that on some occasions there does not appear to be anything overtly Irish about characters in a film, yet the publicity material provided by production and/ or distribution companies assigned Irish names or character traits. For example, Kevin Rockett notes that a French film by Georges Méliès entitled Le Mariage De Victorine was retitled for exhibition in the United States as How Bridget's Lover Escaped (Méliès: 1907). As Rockett argues, 'the choice of American release title ... is not unconnected to the fact that two of the central characters are a cook and a policeman, established Irish cinematic characters by this time' (1996: 242). I have encountered similar examples of this phenomenon in my own research. In the 1950s Kemp Niver was given the task of preserving the paper prints of early films which had been submitted to the Library of Congress for copyright purposes prior to 1912. As part of that task, he compiled a catalogue of the collection which includes synopses of the films based on his viewing. Certain disparities come to light when one compares Niver's readings of the films with material provided by production companies at the time of the films' release and reproduced in contemporary trade press.

According to Niver (1985: 338) The Truants (AM\&B, 1907) 'concerns the pranks of two boys ... as they tie a balloon to the tail of a large dog and ending with ... them being chastised by a spanking in 
the judge's chambers'. A review of the film in Moving Picture World, however, identifies two characters which do not appear in Niver's synopsis - Biddy the cook and 'her friend, the cop' (1907b: 90). In The Yellow Peril (Biograph, 1908), a jealous employer replaces her French maid with a Chinese manservant. Moving Picture World's review of the film points to the character of Bridget the housekeeper, described as being 'of pronounced Hibernian proclivities [with] a strong aversion for anything yellow'. Here too Bridget's relationship with the cop is referred to - they have 'a tacit understanding' and he visits her regularly (1908b: 192). The housekeeper is not mentioned at all in Niver's summary of the film (1985: 372-3). Caught By Wireless (Biograph, 1908) concerns, according to Niver, a man 'forced to flee from his country because of an altercation with a rent collector' (1985: 50). Moving Picture World, however, explicitly states that the opening scenes of the film are set in Ireland and that the main character is a young man forced to leave his wife and children for America on account of 'a despotic land agent'. Once in America he is appointed to the police force, earns enough money for his family to join him, and is ultimately able to bring the land agent to justice (1908a: 241). Niver (1985: 64) describes Monday Morning in a Coney Island Police Court (Biograph, 1908) as 'a burlesque of the day's activities of a police court'. Yet again, however, contemporary reports highlight Irish characters which do not seem to have been apparent to Niver. According to the review in Moving Picture World the judge in court is Patrick Henry McElheeney and the attorneys are named as Ignatius O'Brien and Diogenes Cassidy. The first prisoner is named as Happy Hooligan, a common character in films of the day based on the comic strip Irish tramp created by Frederick Burr Opper (1908c: 181). This raises the question of why Irish names and perceived traits were assigned to characters in early films, and by whom. I hope to explore this question in more detail as my research develops.

\section{Ethnic stereotypes as assimilationist tool}

What purpose then might these sorts of ethnic stereotypes have served? It is possible to see such stereotypical portrayals as symbolic of a wider racism and an expression of nativist hostility and resentment towards immigrants (Mintz, 1996: 24). While there was certainly hostility towards the Irish in America, by the period in question this was beginning to be directed towards more recent immigrants from Southern and Eastern Europe. Charles Musser has proposed that ethnic humour could also be seen as a way for early American film audiences to 'negotiate, question, accept and sometimes even challenge their situation'. In this way, Musser argues, ethnic comedy helped to establish what he terms 'societal norms' and identify undesirable traits and characteristics which could then be mocked. Immigrants in the audience could laugh at their more naive counterparts on 
the screen and also learn what behaviours were and were not acceptable in their new society. The fact that 'native' Americans were also mocked in films featuring the American 'rube' or Uncle Josh character leads Musser to conclude that 'rather than being [merely] expressions of nativist sentiment ... [the films] offer a point of view that urges accommodation to the dynamism of urban life' (Musser, 1991: 48). In addition, Musser argues that ethnic stereotypes allowed immigrant audiences in the United States to understand their ethnicity as merely a construction which could be cast off, allowing immigrants to forge a new, American identity for themselves (1991: 42-3).

I would suggest that the question of how ethnic stereotypes might have functioned in vaudeville and early film also ties in with the debates around the audience for these mass media. Vaudeville claimed to be cleaning up its act and was aware that it could not afford to alienate certain groups within its audience. B.F Keith, the vaudeville entrepreneur, demanded that all material which might be offensive to Jewish, Irish or Yankee audiences be cut from performances in his theatres (Cripps, 1975: 193). In 1895, a black vaudeville performer complained that derogatory terms for African Americans were permitted while a sign backstage at Keith's Boston theatre warned that terms such as 'mick', 'kike', 'sheeny', 'wop' and 'dago' were forbidden (New York Times, 1895 cited in Freeland, 2009: 137). There is some evidence that audiences and critics alike were becoming tired of unsophisticated, stereotypical portrayals of ethnic groups. In 1903 a review in Variety praised the vaudeville team of Mark Murphy and his wife for an act which was 'the essence of real Irish humour that is a thing apart from the spurious imitations of the ordinary witticism of knockabouts wearing green whiskers and talking with an insistently rolling "R"” (cited Staples, 1984: 86-7). By 1898, the vaudeville entrepreneur B.F Keith proclaimed that 'the character of the vaudeville audience has notably improved in recent years, and the entertainment of today is freely patronized and enjoyed by the most intelligent and cultivated people' (cited Lewis 2003: 334).

For early film, Russell Merritt has pointed to a similar process that he describes as 'the seduction of the affluent' (1976: 60, 72), whereby early film exhibitors and producers made conscious efforts to distance themselves and their products from the urban, immigrant working classes in favour of a more respectable, middle-class family audience. Part of the evidence he cites for this is the fact that very few films dealt with either immigrants or the working class. From the examples I have cited though, I would argue that both vaudeville acts and early film did use material which drew on the experiences of the Irish in America, albeit often not in a sympathetic manner. In doing so, what might these sketches and films have been trying to say? Given that by the turn of the twentieth century the Irish were moving or had moved up the ladder, and that those employed in the most menial jobs tended to be recent immigrants, it is perhaps possible to use the examples of the naive 
and foolish Irish working man and woman presented in vaudeville acts and films of this period as evidence to support Musser's argument. In these characters it was perhaps not Irish America that was being mocked, but those immigrants newly arrived from Ireland who had not been schooled in the ways of America. Yet Irish America was mocked, particularly the growing ranks of the 'lace curtain', middle class Irish. Williams (2002: 9-10) has argued that 'lace curtain' satires highlight the ambivalent position of the Irish in America. To achieve prosperity in America, which was surely the goal, Irish immigrants had to leave behind their immigrant, working class roots. In doing so, they once again placed themselves in unfamiliar situations, almost a 'second immigration'. So these satires might also be read as a way of defining acceptable and unacceptable behaviours and addressing Irish concerns about the risks they were taking and the communities they were leaving behind once again.

In this sense early films' representations of ethnicity can be seen as an assimilationist tool. Thomas Cripps, in his study of 'the movie Jew', argues that early American cinema's portrayal of Jewish characters as largely virtuous and likeable served to lessen wider anti-Semitic stereotypes (1975: 190). There is some evidence to suggest that representations of the Irish on stage and screen softened over time. In his study of the Irish in American popular music in the late nineteenth and early twentieth centuries, for example, Williams notes the evolution of the Irish stereotype from the Irish peasant Paddy, through to the urban, working-class Irish American Pat, to the Irish made good, the 'micks on the make' or 'solid men' (1996: 138). The gradual change of emphasis of Irish representations from uncouth and naive working men and women to the foremen and the cop, beneficiaries of the American dream, might be read as a way of suggesting to both new arrivals and native-born Americans that it is entirely possible for immigrants to 'fit in' and become a successful 'American', despite their ethnicity. As Joseph Curran has argued, 'by reflecting and sometimes influencing their audience's changing perception of the Irish, motion pictures facilitated their assimilation into American society, helping to raise both their status and aspirations' (1989: xvi).

That early producers recognised cinema's potential role in this process is perhaps evidenced by two of the films referred to above. In both Congress of Nations and Fights of Nations, having presented stereotypical portrayals of various ethnic groups, the films end with the appearance of the American flag which serves to unite the various parties. The final section of Fights of Nations is entitled 'America: The Land of the Free' and, according to Biograph's own publicity material,

'America' ... serves as an appropriate finale. The scene is magnificently decorated with emblems of all nations, the American eagle surmounting them. In harmony, peace and goodwill the characters of the different nations appear, making it an allegorical 
representation of 'peace', with Uncle Sam presiding at a Congress of the Powers. (1907 cited Library of Congress American Memory Collection: online reference)

Such grand claims on behalf of the production companies should of course be treated with caution. For example, there are no black characters presented in this scene and nor do there appear to be any recognisable Irish characters.

However, in order to try to understand the role of ethnic stereotypes in vaudeville and early film it is important to consider the role which ethnic groups themselves had in shaping and negotiating their representations in popular culture. While the vaudeville stage borrowed Irish stereotypes from other, less sympathetic sources, they were often reworked by Irish performers. Snyder (2006: 406) suggests that the Irish contribution to vaudeville in terms of performers, businessmen, and audiences transformed American and Irish-American culture. According to Snyder, 'Irish acts... were a striking presence on the vaudeville stage' (2000: 48). Williams lists a range of Irish and Irish-American vaudeville acts including Harrigan and Hart, Maggie Cline, Kitty O'Neal, McNulty and Murray known as The Boys from Limerick, Kelly and Ryan also known as The Bards of Tara, and Irish 'four-acts' such as The Four Shamrocks, The Four Emeralds and The Four Cohans (1996: 119). According to Williams the Irish were particularly heavily involved in minstrelsy with performers such as R.M Hooley and Chauncey Olcott (1996: 65). So as well as negotiating their own representations on the stage, which Williams (1996: 66) argues were becoming more positive, they played a crucial role in developing and fostering a more insidious stereotype of black Americans. With the rise of motion pictures, it would appear that the Irish had less control over their portrayals than they had in vaudeville. It has been suggested that early films' representations of Irish characters were as seen through the eyes of native-born film producers or other immigrant groups, and that the Irish did not have a significant role in the power structure of the movie business (Clark and Lynch 1980: 105-07). Robert Sklar suggests that 'before 1910 the movies were as completely in the hands of respectable, established Anglo-Saxon Protestants as they were ever to be' (Sklar, 1975: 33). As Charles Musser argues, early films 'strongly reflect the values characteristic of ... the predominantly WASP urban filmmakers who produced them' (Musser, 1991: 47).

\section{Conclusion}

Above I have discussed some examples of Irish stereotypes which were prevalent on the vaudeville stage and in early films around the turn of the twentieth century. I have tried to place these in the 
Networking Knowledge: Journal of the MeCCSA Postgraduate Network, Vol. 3, No. 2 (2010)

historical context of the changing socio-economic position of the Irish in the United States. I have discussed how 'Irishness' appears to have been assigned by contemporary publicity material, which I believe raises complex questions - why were Irish names or apparent personality traits given to characters and how obvious might this 'Irishness' have been to a contemporary audience? In addition, the representations of the Irish in vaudeville and early cinema referred to above are not meant to suggest that the relationship between the Irish and American popular culture during this period was an entirely negative one. Clearly the Irish were not the only people to have been portrayed negatively, and indeed they fared much better than some other ethnic groups. In some cases it was the Irish themselves who had a hand in their own portrayal and indeed in the portrayals of others. However, I would draw some conclusions from the examples I have used. As the Irish moved up the ladder, so too did their representations develop. I would suggest that the stereotypical portrayals of the naïve, ignorant Irish working man and woman, represented by the Caseys, Brannigans and Bridgets, and the rising 'lace-curtain' Irish seen in the figures of the Irish cop or politician, can be read in the context of establishing and defining acceptable behaviours, allowing a proportion of the audience to recognize how they should behave in order to be accepted as fully fledged Americans, leaving behind the brash, boisterous Irish so apparent in the caricatures presented on stage and screen. I would also argue that these representations can add to the debates on the nature of that audience. Russell Merritt, writing of early cinema's 'seduction of the affluent', cites as evidence for this the fact that it did not address the experiences of the immigrant and working classes traditionally perceived as cinema's natural audience base (Merritt, 1976). I would suggest, at least in relation to the Irish, that neither vaudeville nor early cinema ignored their experiences, but rather used them as often comic material for what appears to have been an increasingly respectable, middle class, and perhaps ultimately 'American' audience. 


\section{References}

Allen, R.C. (1977) Vaudeville and Film, 1895-1915: A Study in Media Interaction, PhD

Dissertation. Ann Arbor, MI: University of Iowa

Bertellini, G. (1999) 'Italian Imageries, Historical Feature Films, and the Fabrication of Italy's Spectators in Early 1900s New York' In: Stokes, M., and Maltby, R., (eds.) American Movie Audiences From the Turn of the Century to the Early Sound Era, London: BFI, pp. 29-45

Blessing, P.J. (1980) 'The Irish’ In: Thernstrom, S. (ed.) Harvard Encyclopedia of American Ethnic Groups, Cambridge, Mass.: Belknap Press, pp. 524-545

Clark, D. \& Lynch, W.J. (1980) 'Hollywood and Hibernia: The Irish in the Movies' In: Miller, R.M. (ed.) The Kaleidoscopic Lens: How Hollywood Views Ethnic Groups, Englewood, N.J.: Jerome S. Ozer, pp. 98-113

Cripps, T. (1975) 'The Movie Jew as an Image of Assimilation, 1903-1927', Journal of Popular Film, 4, 3: 190-207

Curran, J.M. (1989) Hibernian Green on the Silver Screen: The Irish and American Movies. New York: Greenwood Press

Curtis, L.P. (1997) Apes and Angels: The Irishman in Victorian Caricature. Rev. ed. London: Smithsonian Institute Press

Dinnerstein, L. \& Reimers, D.M. (1977) Ethnic Americans: A History of Immigration and Assimilation. New York: New York University Press

Fights of Nations (1907), publicity material [Online]. Available from http://memory.loc.gov/cgibin/query/r?ammem/varstg: @ field(NUMBER(2412s1)) [accessed 03.09.10]

Freeland, D. (2009) Automats, Taxi Dances and Vaudeville: Excavating Manhattan's Lost Places of Leisure. New York: New York University Press

Friedman, L.D. (1987) 'Celluloid Assimilation: Jews in American Silent Movies', Journal of Popular Film and Television, 15, 3: 129-136 
Networking Knowledge: Journal of the MeCCSA Postgraduate Network, Vol. 3, No. 2 (2010)

Gaskell, H.S. \& Landrum, R.L (1911) The Irish American Ex Congressman: A Comedy Vaudeville

Playlet. Available from: http://memory.loc.gov/cgi-bin/ampage?collId=varsep\&fileName=s28039/

s28039.data\&recNum=0\&Layout=Unscaled\&itemLink=D?varstg:7:./temp/ ammem_CWJf::

[accessed 02.09.10]

Jacobs, L. (1968) The Rise of the American Film. New York: Teachers College Press

Kenny, K. (2000) The American Irish: A History. Harlow: Longman

Kibler, M.A. (2005) ‘The Stage Irishwoman’, Journal of American Ethnic History, 24, 3: 5-30

Kimmel, M.S. (2006) Manhood in America: A Cultural History. 2nd edn. New York: Oxford University Press

Lewis, R.M. (ed.) (2003) From Travelling Show to Vaudeville: Theatrical Spectacle in America, 1830-1910. Baltimore, MD.: John Hopkins University Press

Martin, F.X. (1969) 'Gerald of Wales, Norman Reporter on Ireland', Studies: An Irish Quarterly Review, 58, 231: 279-292

Merritt, R. (1976) 'Nickelodeon Theatres 1905 - 1914: Building an Audience for the Movies' In:

Balio, T. (ed.) The American Film Industry, Madison, Wis.: University of Wisconsin Press, pp. 5979

Miller, K. (1985) Emigrants and Exiles: Ireland and the Irish Exodus to North America. Oxford: Oxford University Press

Mintz, L.E. (1996) 'Humor and Ethnic Stereotypes in Vaudeville and Burlesque', MELUS, 21, 4: $19-28$

Moloney, M. (2006) McNally's Row of Flats: Irish American Songs of Old New York, by Harrigan and Braham. Nashville, TN.: Compass Records

Moving Picture World(1907a), 1, 16, 22 June

Moving Picture World (1907b), 1, 6, 13 April

Moving Picture World (1908a), 2, 12, 21 March 
Networking Knowledge: Journal of the MeCCSA Postgraduate Network, Vol. 3, No. 2 (2010)

Moving Picture World (1908b), 2, 10, 07 March

Moving Picture World (1908c), 3, 10, 05 September

Moving Picture World (1909), 5, 27, 31 December

Moving Picture World (1910a), 6, 22, 04 June

Moving Picture World (1910b), 7, 10, 03 September

Musser, C. (1991) 'Ethnicity, Role-Playing, and American Film Comedy: From Chinese Laundry Scene to Whoopee (1894-1930)' In: Friedman, L.D. (ed.) Unspeakable Images: Ethnicity and the American Cinema, Chicago: University of Illinois Press, pp. 39-81

The Nickelodeon (1910a), 4, 3, 01 August

The Nickelodeon (1910b), 4, 12, 15 December

Niver, K.R. (1985) Early Motion Pictures: The Paper Print Collection in the Library of Congress. Washington, D.C.: Library of Congress

O'Connell, B. (2010) 'Will we ever beat the Irish stereotype?', The Irish Times, 26 May [Online]. Available from http://www.irishtimes.com/newspaper/features/2010/0526/1224271139965.html [accessed 02.09.10]

O'Malley, A. (1918) 'Irish Vital Statistics in America', Studies: An Irish Quarterly Review, 7, 28 : 623-632

Pickering, M. (2001) Stereotyping: The Politics of Representation, New York: Palgrave

Policeman O'Reilly on Duty (1909), performed by Steve Porter, Edison Standard Record [Online]. Available from http://cylinders.library.ucsb.edu/search.php?queryType=@ $\operatorname{attr\% 201=1020\& }$ $\underline{\text { num }=1 \& \text { start=1\&query=cylinder3523 }}$ [accessed 02.09.10]

Rockett, K. (2009) ‘The Irish Migrant and Film’ In: Barton, R. (ed.) Screening Irish-America: Representing Irish-America in Film and Television, Dublin: Irish Academic Press, pp. 17-44

Rockett, K. (1996) The Irish Filmography: Fiction Films, 1896 - 1996. Dublin: Red Mountain Press 
Networking Knowledge: Journal of the MeCCSA Postgraduate Network, Vol. 3, No. 2 (2010)

Sklar, R. (1975) Movie-Made America: A Cultural History of American Movies. London: Chappell

Snyder, R.W. (2006) 'The Irish and Vaudeville' In: Lee, J.J., and Casey, M.R. (eds.) Making the Irish American: History and Heritage of the Irish in the United States, New York: New York University Press, pp. 406-410

Snyder, R.W. (2000) Voice of the City: Vaudeville and Popular Culture in New York. 2nd edn. Chicago: I.R. Dee

Staples, S. (1984) Male-Female Comedy Teams in American Vaudeville, 1865-1932. Ann Arbor, Mich.: UMI Research Press

Thissen, J. (1999) 'Jewish Immigrant Audiences in New York, 1905-14' In: Stokes, M., and

Maltby, R., (eds.) American Movie Audiences From the Turn of the Century to the Early Sound Era, London: BFI, pp. 15-28

Variety (1906), 1, 12, 03 March

Variety (1907), 9, 1, 14 December

Williams, W.H.A. (2002) 'Green Again: Irish American Lace Curtain Satire', New Hibernia Review, 6, 2: 9-24

Williams, W.H.A. (1996) 'Twas Only an Irishman's Dream: The Image of Ireland and the Irish in American Popular Song Lyrics 1800-1920. Chicago: University of Illinois Press

Wittke, C. (1970) The Irish in America. 2nd edn. New York: Russell \& Russell

\section{Filmography:}

Note: I have indicated in parenthesis those films held in the Library of Congress (LOC) motion picture archives.

Brannigan Sets Off the Blast (1906). USA, American Mutoscope \& Biograph Company (LOC)

Casey’s Frightful Dream (1904). Directed by Edwin S. Porter, USA, Edison (LOC)

Caught by Wireless (1908). USA, Biograph (LOC) 
Networking Knowledge: Journal of the MeCCSA Postgraduate Network, Vol. 3, No. 2 (2010)

Chinese Rubbernecks (1903). USA, American Mutoscope \& Biograph Company (LOC)

Clancy (1910). USA, Vitagraph

Cohen's Advertising Scheme (1904). USA, Edison (LOC)

Congress of Nations (1900). USA, Edison (LOC: available to view online at http://memory.loc.gov/cgi-bin/query/D?papr:84:./temp/ ammem_FHx6:: [accessed 10.11.2010]

Drill Ye Tarriers Drill (1900). USA, American Mutoscope \& Biograph Company (LOC)

Fights of Nations (1907). USA, American Mutoscope \& Biograph Company (LOC: available to view online at http://memory.loc.gov/cgi-bin/query/r?ammem/varstg:@ field(NUMBER(2412s1)) [accessed 03.09.10])

The Godfather (1972). Directed by Francis Ford Coppola, USA, Paramount Pictures

How Bridget Made the Fire (1900). USA, American Mutoscope \& Biograph Company (LOC)

How Bridget Served the Salad Undressed (1898). USA, American Mutoscope Company (LOC)

How Bridget's Lover Escaped (1907). France, Méliès (LOC)

Maggie Hoolihan Gets a Job (1910). France, Pathé-Frères

Monday Morning in a Coney Island Police Court/ Alternative title Coney Island Police Court (1908). USA, Biograph (LOC)

Mulcahy's Raid (1910). USA, Essanay

Officer Muldoon's Double (1910). USA, Lubin

The Policeman's Revolver (1909). USA, Essanay

The Quiet Man (1952). Directed by John Ford, USA, Argosy Pictures

A Son of Erin (1916). USA, Pallas Pictures (LOC)

The Troubles of a Policeman (1910). France, Pathé

The Truants (1907). USA, American Mutoscope \& Biograph Company (LOC) 
Networking Knowledge: Journal of the MeCCSA Postgraduate Network, Vol. 3, No. 2 (2010)

When Women Vote (1907). USA, Lubin

Where is Mulcahy? (1910). USA, Essanay

Why Bridget Stopped Drinking (1901). USA, Edison

The Yellow Peril (1908). USA, American Mutoscope \& Biograph Company (LOC) 